\title{
New records and range extensions of reef fishes in the Western South Atlantic, with comments on reef fish distribution along the Brazilian coast
}

\author{
Rodrigo Leão de Moura ${ }^{1}$ \\ João Luiz Gasparini ${ }^{2}$ \\ Ivan Sazima ${ }^{3}$
}

\begin{abstract}
New occurrences of 11 species of reef fishes are reported for the western South Atlantic, range extensions are recorded for additional 37 reef species along the Brazilian coast, and the distribution of reef ichthyofauna along the eastern coast of South America is commented upon.

KEY WORDS. Western South Atlantic, Brazilian ichthyofauna, reef fishes, new records, range extensions, latitudinal trends
\end{abstract}

There is no reliable, recent compilation of the Brazilian marine ichthyofauna, not even for a particular geographical area, despite the continuous and well succeeded efforts of Figueiredo (1978), Figueiredo \& MENEZES $(1978,1980)$ and MENEZES \& FigUEIREDO $(1980,1985)$ for southeastern Brazil, and two major contributions by Roux $(1973,1979)$ for the whole Brazilian coast. As an immediate consequence, no one knows exactly which and how many fish species are recorded for the Brazilian coast, nor what is the reported range of most marine fishes in this region of the western South Atlantic.

In recent years there has been a steady increase of new records of marine fishes on the Brazilian coast, especially of reef species (ROSA 1980; LUBBOCK \& EDWARDS 1981; KOIKE \& GUEDES 1981; RAMOS \& VASCONCELLOS-FILHO 1989; MOURA 1995; GUIMARÃES 1996a,b; RoCHA et al. 1998). The presence of previously unrecorded species indicate that the Brazilian reef ichthyofauna is considerably richer and an estimation of number, composition and distribution of species is still far from being obtained.

In this paper, we report on new occurrences of 11 species of reef fishes in the western South Atlantic, record range extensions of additional 37 species, and comment upon the distribution and composition of the Brazilian reef ichthyofauna. Some of the species presented herein had been listed in a popular account on

1) Seção de Peixes, Museu de Zoologia da Universidade de São Paulo. Caixa Postal 42694, 04299-970 São Paulo, São Paulo, Brasil.

E-mail: rlmoura@usp.br

2) Departamento de Biologia, Universidade Federal do Espírito Santo. Caixa Postal 5130, 29041-970 Vitória, Espirito Santo, Brasil.

3) Departamento de Zoologia e Museu de História Natural, Universidade Estadual de Campinas. Caixa Postal 6109, 13083-970 Campinas, São Paulo, Brasil. 
Brazilian marine fishes (CARVALHO-FILHO 1992) and on a recent paper (ROCHA et al. 1998) without, however, any reference to specimens, these species being thus substantiated as new occurrences in the present paper.

\section{MATERIAL AND METHODS}

Most of the material reported in this study was sporadically collected since 1980 by divers at several localities from the State of Maranhão (about $00^{\circ} 52^{\prime}$ 'S) south to the State of Espirito Santo (about $20^{\circ} 45^{\prime}$ 'S), the southern limit of the intense coral reef growth in the western South Atlantic, and from the State of Espirito Santo south to the State of Santa Catarina (about $27^{\circ} 09^{\prime} \mathrm{S}$ ), the southern limit of rocky reefs along the Brazilian coast. Collections were made also on the oceanic islands of the Atol das Rocas, Fernando de Noronha Archipelago, and Trindade Island.

Specimens examined are deposited at the Museu de Zoologia, Universidade de São Paulo (MZUSP), Museu de História Natural, Universidade Estadual de Campinas (ZUEC); Departamento de Sistemática e Ecologia, Universidade Federal da Paraíba (UFPB), and Laboratório de Ictiologia Geral e Aplicada, Universidade Federal do Rio de Janeiro (UFRJ). The specimens are presented from northern to southern localities. Coordinates are given when a locality first appears within the text, both latitude and longitude for oceanic islands, and only latitude for coastal localities including continental islands.

For each specimen, collection number, number of specimens in parentheses, standard length in millimeters (total length for eels and shark embryo), locality, date of collection, and collectors are given and depth at collection site is also presented when available. Taxonomic arrangement follows NELSON (1994).

\section{RESULTS AND DISCUSSION}

\section{Ophichthidae}

\section{Myrichthys breviceps (Richardson, 1848)}

Specimens examined. BrazIL, Espírito Santo: Guarapari (Meaípe, 2045'S, tidepool), ZUEC 3066 (1), 295 mm, 1-VII-1996, C. Sazima, J.L. Gasparini \& I. Sazima leg.; São Paulo: São Sebastião (Arquipélago dos Alcatrazes, 2406'S), MZUSP 45652 (1), 720 mm, 27-IV-1993, R.L. Moura leg. .

Remarks. Represents a south range extension of the sharptail eel, previously reported at about $15^{\circ} \mathrm{S}$ (MCCOSKER et al. 1989).

\section{Ophichthus ophis (Linnaeus, 1758)}

Specimens examined. BrazIL, São Paulo: Santos (Laje de Santos, $24^{\circ} 19^{\prime}$ 'S, 21 m), MZUSP 44649 (1), 919 mm, 21-III-1992, R.L. Moura leg. .

Remarks. The spotted snake eel was previously recorded south of the State of Rio de Janeiro, southeastern Brazil (MCCosKeR et al. 1989). This eel is expected to occur further south, at least to the State of Santa Catarina, based on its abundance on the State of São Paulo coast, from where our specimen was obtained. 


\section{Congridae}

\section{Heteroconger longissimus Günther, 1870}

Specimens examined. BraZIL, São Paulo: São Sebastião (Arquipélago dos Alcatrazes, 16 m), MZUSP 49456 (1), 443 mm, 1-III-1996, I. Sazima, R.L. Moura \& C. Sazima leg..

Remarks. The known southernmost record for the Caribbean brown garden eel was the Caribbean (SMITH 1989). Our specimen has 157 vertebrae, which is at the lower range (157-179) of vertebral counts for both Eastern and Western Atlantic specimens (SMITH 1989; GONZÁLEZ-LORENZO et al. 1995). Heteroconger halis (Böhlke) is a junior synonym of $H$. longissimus (SALDANHA et al. 1986; GonZÁLEZ-LORENZO et al. 1995).

\section{Bythitidae}

\section{Stygnobrotula latebricola (Böhlke, 1957)}

Specimens examined. BRAzIL, Espírito Santo: Guarapari (Ilha Escalvada, 2042’S, 19 m), ZUEC 2740 (1), 74.3 mm (tip missing), 26-VII-1994, D.A. Jório \& J.L. Gasparini leg.

Remarks. Represents a south range extension, as the southernmost record of the black brotula was at Salvador (about $13^{\circ} \mathrm{S}$ ), State of Bahia, northeastern Brazil (ALMEIDA 1973).

\section{Antennariidae}

\section{Antennarius multiocellatus (Valenciennes, 1837)}

Specimens examined. BRAzIL, Pernambuco: Arquipélago de Fernando de Noronha (0356'S, 32²4'W), MZUSP 46345 (1), 72.3 mm, IV-1990, A. Carvalho

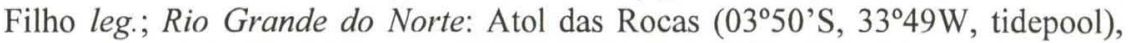
MZUSP 48229 (1), 13.7 mm, 16-XII-1994-10-I-1995, R.L. Moura \& C.L.B. Francini leg.; Espirito Santo: Guarapari (Enseada de Perocão, 20 $40^{\circ} \mathrm{S}, 10 \mathrm{~m}$ ), ZUEC 2748-2750 (3), 76.5-105.6 mm, V-1995, D.A. Jório leg. .

Remarks. This is the first record in oceanic islands in the western South Atlantic and a south range extension for the longlure frogfish, previously recorded south to Salvador, State of Bahia (PIETSCH \& GROBECKER 1987).

\section{Ogcocephalidae}

\section{Halieutichthys aculeatus (Mitchill, 1818)}

Specimens examined. BrazIL, Espírito Santo: Linhares (Foz do Rio Doce, $19^{\circ} 42^{\prime}$ 'S, 60 m), MZUSP 51316 (1), 54.2 mm, XI-1984, J.L. Gasparini leg. .

Remarks. First substantiated record in the western South Atlantic (RouX 1973). The record of Halieutichthys caribbaeus Garmann, 1897 for the Brazilian coast (Roux 1973) probably refers to this species. The previous southernmost record for the pancake batfish was in the Caribbean (BRADBURY 1967; BÖHLKE \& CHAPLIN 1968). 


\section{Holocentridae}

\section{Plectrypops retrospinis (Guichenot, 1853)}

Specimens examined. BraziL, Pernambuco: Arquipélago de Fernando de Noronha, MZUSP 46336 (2), $77.1 \mathrm{~mm}$, VII-1995, A. Carvalho Filho leg.; Espírito Santo, Guarapari, (Ilhas Rasas, 2040'S, 22 m), ZUEC 3104 (1), 84.1 mm, 8-VII1996, D.A. Jório leg.; São Paulo, São Sebastião (Praia de Toque-Toque, 2350'S), MZUSP 46993 (1), 55.5 mm, II-1987, A. Carvalho Filho leg..

Remarks. First substantiated record for the cardinal soldierfish in the western South Atlantic (CARVALHO-FILHO 1992; ROCHA et al. 1998); previous records south to Venezuela (MAGO-LECCIA 1965).

\section{Serranidae}

\section{Liopoproma carmabi (Randall, 1963)}

Specimens examined. BRAZIL, Espirito Santo: Guarapari (Ilha Escalvada, 16m), MZUSP 44934 (1), 58.5 mm, 3-VIII-1986, J.L. Gasparini \& F. Pavan leg.; Guarapari (Ilhas Rasas, 27 m), ZUEC 2648 (1), 48.0 mm, 24-X-1995, D.A. Jório \& J.L. Gasparini leg. .

Remarks. The known southernmost record for the candy basslet was in the Caribbean (RANDALL 1963, 1983).

\section{Serranus baldwini (Evermann \& Marsch, 1900)}

Specimens examined. BRAZIL, São Paulo: São Sebastião (Arquipélago dos Alcatrazes, 15 m), MZUSP 45619 (1), 52.0 mm, 29-IV-1993, R.L. Moura leg.; Santos (Laje de Santos, 12 m), MZUSP 43479 (1), 43.4 mm, 21-IV-1991, R.L. Moura leg.; Itanhaém (Ilha da Queimada Grande, 2429'S, 10 m), MZUSP 43480 (1), 50.8 mm, 20-IX-1991, R.L. Moura leg. .

Remarks. Represent a south range extension, as the southernmost record for the lantern bass was the State of Rio de Janeiro (MENEZES \& FigUEIREDO 1980). It is expected to occur further south at least to the State of Santa Catarina, since this is one of the most abundant small serranids on the coastal islands of the State of São Paulo.

\section{Rypticus bistrispinus (Mitchill, 1818)}

Specimens examined. BRAZIL, Bahia: Arembepe ( $12^{\circ} 47^{\prime}$ 'S), MZUSP 46382 (1), $74.4 \mathrm{~mm}, 10$-VI-1985, A. Carvalho Filho leg.; Rio de Janeiro: Arraial do Cabo (Praia do Forno, 22 ${ }^{\circ} 58^{\prime}$ 'S), MZUSP 47483 (2), 64.6 and $62.1 \mathrm{~mm}, 16-\mathrm{V}-1991$, C.E.L. Ferreira leg.

Remarks. Represent a south range extension, as the southernmost record for this soapfish was northern Brazil, about 0150'S (COURTENAY 1967).

\section{Rypticus randalli Courtenay, 1967}

Specimens examined. Brazil, Santa Catarina: Porto Belo (27 $\left.09^{\prime} \mathrm{S}\right)$, MZUSP 46648 (1), I-1988, A. Carvalho Filho leg. .

Remarks: The southernmost record for this soapfish was the State of São Paulo, southeastern Brazil (MENEZES \& FIGUEIREDO 1985). 


\section{Opistognathidae}

\section{Opistognathus aurifrons (Jordan \& Thompson, 1905)}

Specimens examined. BRAZIL, Espírito Santo: Vitória (20¹7'S), MZUSP 46541 (1), XII-1990, A. Carvalho Filho leg.; Guarapari (Ilha Escalvada, 16 m), ZUEC 2739 (1), 60.2 mm, VII-1995, D.A. Jório \& J.L. Gasparini leg.; Rio de Janeiro: Armação dos Búzios (Praia dos Ossos, 22²4'S), MZUSP 49070 (1), 62.9 mm, IX-1987, A. Carvalho Filho leg. .

Remarks. The yellowhead jawfish was previously recorded south to the State of Alagoas, northeastern Brazil (RAMOS 1994).

\section{Priacanthidae}

\section{Heteropriacanthus cruentatus (Lacépède, 1801)}

Specimens examined. Brazıl, São Paulo: São Sebastião (Praia de Baraqueçaba, 2349'S), MZUSP 46260 (1), 56.2 mm, I-1991, A. Carvalho Filho leg.; São Sebastião (Arquipélago dos Alcatrazes), ZUEC 2732 (1), 80.1 mm, \&-IV-1996, I. Sazima, R.L. Moura \& C. Sazima leg.

Remarks. Although the presence of the glasseye snapper would be expected in southeastern Brazil, no specimens were previously reported from the area between the State of Rio de Janeiro in Brazil and Argentina (FIgUeIREDo \& MENEZES 1980; STARNES 1988).

\section{Apogonidae}

\section{Apogon americanus Castelnau, 1855}

Specimens examined. BRAZIL, Rio de Janeiro: Arraial do Cabo (Praia do Forno, 6 m), MZUSP 47486 (1), 70.2 mm, 8-II-1991, C.E.L. Ferreira leg.; São Paulo: Ubatuba (Ilha Anchieta, 2332'S, 8 m), ZUEC 2709 (1), 83.1 mm, 24-II1996, I. Sazima, R.L. Moura \& C. Sazima leg.; Santos (Laje de Santos, 5 m), MZUSP 45641 (1), 76.7 mm, 21-II-1992, R.L. Moura leg..

Remarks. Previously recorded south to Bahia, northeastern Brazil (GILBERT 1977). Specimen ZUEC 2709 was brooding eggs orally [see CHARNEY (1976) and BLUMER (1982) for parental care in other species within the genus].

\section{Apogon quadrisquamatus Longley, 1934}

Specimens examined. BRAzIL, Rio de Janeiro: Cabo Frio (Praia dos Anjos), MZUSP 46139 (1), 38.8 mm, XII-1989, A. Carvalho Filho leg.; Parati (Ilha Comprida, 23ํ'13'S), MZUSP 46196 (2), 41.6 and 43.9 mm, VII-1992, A. Carvalho Filho leg.; São Paulo: São Sebastião (Arquipélago dos Alcatrazes, $6 \mathrm{~m}$ ), MZUSP 45631 (3), 38.2 and $42.7 \mathrm{~mm}, 18-\mathrm{V}-1991$, R.L. Moura leg. .

Remarks. First substantiated record for the western South Atlantic (CARVALHO-FILHO 1992); previous southernmost record on the northern coast of South America (BöHKLE \& RANDALL 1968). 


\section{Astrapogon puncticulatus (Poey, 1867)}

Specimens examined. BRAZIL, Rio de Janeiro: Arraial do Cabo (Ilha de Cabo Frio, 7 m): MZUSP 47487 (2), 37.9 and 42.0 mm, 3-V-1990, C.E.L. Ferreira leg.; São Paulo: Ubatuba (Ilha Anchieta, 8 m), ZUEC 2710-2711 (2), 33.9 and 34.4 mm, 24-II-1996, I. Sazima, R.L. Moura \& C. Sazima leg.; São Sebastião (Arquipélago dos Alcatrazes, 4 m), MZUSP 49455 (1), 21.3 mm, 29-II-1996, II-1996, I. Sazima, R.L. Moura \& C. Sazima leg. .

Remarks. Previously recorded south to the State of Bahia, northeastern Brazil (GILBERT 1977). Specimen ZUEC 2710 was brooding eggs orally.

\section{Astrapogon stellatus (Cope, 1869)}

Specimens examined. BraziL, Rio Grande do Norte: Atol das Rocas, MZUSP 48924 (2), 22.6 and 31.2 mm, 22-VII-1995, R.S. Rosa \& R.L. Moura leg.; Rio de Janeiro: (Baía da Ilha Grande, 2307'S), UFRJ 3518 (1), 1995, R.Z.P. Guimarães leg..

Remarks. Previous southernmost record was at an offshore locality in northeastern Brazil (RAMOS 1994).

\section{Phaeoptyx pigmentaria (Poey, 1861)}

Specimens examined. BraziL, Rio de Janeiro: Arraial do Cabo (Praia do Forno, $13 \mathrm{~m}$ ), MZUSP 47491 (2), 49.0 and $50.3 \mathrm{~mm}, 20-X-1990$, C.E.L. Ferreira leg.; Cabo Frio (Praia dos Anjos), MZUSP 46137 (2), 43.3 and 44.4 mm, XII-1989, A. Carvalho Filho leg.

Records. Previously recorded south to the State of Bahia, northeastern Brazil (ALMEIDA 1973).

\section{Haemulidae}

\section{Anisotremus moricandi (Ranzani, 1840)}

Specimens examined. BRAZIL, Espírito Santo: Vitória (Ilha do Boi, 2019'S, 9 m), ZUEC 2743 (1), 139.5 mm, 09-III-1988, J.L. Gasparini leg.; Guarapari (Ilha Escalvada, 12 m), MZUSP 51317 (1), 151.2 mm, 26-I-1997, I. Sazima, C. Sazima, J.L. Gasparini \& R.L. Moura leg..

Remarks. Previously recorded south to the State of Bahia, northeastern Brazil (ACERO \& GARZÓN 1982).

\section{Sciaenidae}

\section{Equetus lanceolatus (Linnaeus, 1758)}

Specimens examined. BraziL, Pernambuco: Arquipélago de Fernando de Noronha, MZUSP 46322 (1), 24.4 mm, 20-23-VI-1985, A. Carvalho Filho leg.; Rio de Janeiro: Parati, MZUSP 46147 (1), 24.0 mm, VII-1994, A. Carvalho Filho leg. .

Remarks. First record for the jackknife fish in an oceanic island in the western South Atlantic (CHAO 1978; MENEZES \& FIGUEIREDo 1980). MZUSP 46147 is the southernmost specimen in collections known to us. Despite extensive collections on the State of São Paulo coast, no specimens of the jackknife fish were obtained 
whereas the cubbyu, Pareques acuminatus (Bloch \& Schneider, 1801), was very common. We guess the unsubstantiated record of $E$. lanceolatus for the State of Rio Grande do Sul, southern Brazil (LEMA 1979) is based on P. acuminatus.

\section{Chaetodontidae}

\section{Chaetodon ocellatus Bloch, 1787}

Specimens examined. BraZIL, Rio de Janeiro: Parati, MZUSP 46153 (1), 47.4 mm, VII-VIII-1991, A. Carvalho Filho leg. .

Remarks. Previous southernmost record for the spotfin butterflyfish in northeastern Brazil (MENEZES \& FIGUEIREDO 1985).

\section{Pomacanthidae}

\section{Centropyge aurantonotus Burgess, 1974}

Specimens examined. BrazIL, São Paulo: São Sebastião (Arquipélago dos Alcatrazes, 12 m), MZUSP 45636 (1), 60.1 mm, 28-V-1993, R.L. Moura leg..

Remarks. Previously recorded south to the State of Rio de Janeiro, southeastern Brazil (MENEZES \& FigueIREDo 1985).

\section{Cirrhitidae}

\section{Amblycirrhitus pinos (Mowbray, 1927)}

Specimens examined. BRAZIL, Bahia: Salvador (1258'S), MZUSP 46826 (1), 65.8 mm, 09-VI-1993, C.L. Sampaio leg.; Espírito Santo: Guarapari (Ilha Escalvada, 10 m), ZUEC 3111 (1), 71.9 mm, X-1996, J.L. Gasparini \& V. C. Vidal leg.; Rio de Janeiro: Cabo Frio, MZUSP 46127 (1), 65.9 mm, II-1991, A. Carvalho Filho leg. .

Remarks. First substantiated record for the western South Atlantic (CARVALHO-FILHO 1992; RocHA et al. 1998), since the redspotted hawkfish was previously recorded south to Venezuela (MAGO-LECCIA 1965; RANDALL 1983).

\section{Pomacentridae}

\section{Chromis jubauna Moura, 1995}

Specimens examined. BRAzIL, Espírito Santo: Guarapari (Ilhas Rasas, 18m), MZUSP 44940 (1), 29.2 mm, XII-1992, D.A. Jório \& J.L. Gasparini leg.; Marataízes (Mar do Bom Nome, 2109'S), ZUEC 2736 (1), 34.1 mm, 10-IV-1996, D.A. Jório leg. .

Remarks. Previously known only from Cabo Frio in the State of Rio de Janeiro, and coastal islands off the State of São Paulo (MOURA 1995).

\section{Chromis scotti Emery, 1968}

Specimen examined. Brazil, Maranhão: São Luís (Recifes Manoel Luís, 0052'S), MZUSP 53089 (1), 57.6 mm, VI-1998, R.L. Moura, R.B. Francini, M.C.M. Rodrigues, F.S. Motta \& A. Carvalho Filho leg..

Remarks. First record for the western South Atlantic (MOURA 1995). 


\section{Microspathodon chrysurus (Cuvier \& Valenciennes, 1830)}

Specimens examined. BRAZIL, Alagoas: Maceió (Ponta Verde, 09³8'S), MZUSP 46361 (1), 82.5 mm, IX-1989, A. Carvalho Filho leg.; Bahia: Camaçari, (Praia de Busca Vida, 12²5'S), MZUSP 47634 (2), 34.1 and $46.5 \mathrm{~mm}, 2$-VI-1984, C.L. Sampaio leg.; Salvador, (Amaralina), MZUSP 46674 (1), 122.2 mm, II-1991, C.L. Sampaio leg.; Espírito Santo: Vitória (Ilha da Trindade), ZUEC 2696(1), 128.6 mm, 8-IX-1995, J.L. Gasparini leg. .

Remarks. First substantiated record for the western South Atlantic (FERREIRA et al. 1995; RocHA et al. 1998) including an oceanic island; previously recorded south to Venezuela (CERVIGÓN 1966). Along the Brazilian coast definitely associated to growths of Millepora coral.

\section{Stegastes fuscus (Cuvier, 1830)}

Specimens examined. BraZIL, Santa Catarina: Porto Belo, MZUSP 46566 (1), $64.9 \mathrm{~mm}, \mathrm{I}-1988$, A. Carvalho Filho leg. .

Remarks. Previously recorded south the State of São Paulo, southeastern Brazil (MENEZES \& FIGUEIREDO 1985).

\section{Stegastes variabilis (Castelnau, 1855)}

Specimens examined. BRAZIL, Santa Catarina: Porto Belo, MZUSP 46555 (1), $55.1 \mathrm{~mm}, \mathrm{I}-1988$, A. Carvalho Filho leg. ; MZUSP 46632 (1), $49.2 \mathrm{~mm}$, same data as MZUSP 46555.

Remarks. Previously recorded south the State of São Paulo, southeastern Brazil (MENEZES \& FigUEIREDO 1985).

\section{Labridae}

\section{Halichoeres bathyphilus (Beebe \& Tee-Van, 1932)}

Specimens examined. BrazIL, Santa Catarina: Porto Belo, MZUSP 46554 (1) $114.0 \mathrm{~mm}, \mathrm{I}-1988$, A. Carvalho Filho leg.

Remarks. Previously recorded south to the State of São Paulo, southeastern Brazil (MENEZES \& FIGUEIREDO 1985).

\section{Halichoeres brasiliensis (Bloch, 1791)}

Specimens examined. BraziL, Maranhão: São Luís (Recifes Manoel Luís), MZUSP 53170 (1), 200.0 mm, VI-1998, R.L. Moura, R.B. Francini, M.C.M. Rodrigues, F.S. Motta \& A. Carvalho-Filho leg.

Remarks. Represents a north range extention; previously recorded as $H$. radiatus (Linnaeus, 1758), from the State of Paraíba, northeastern Brazil (RocHA et al. 1998) south to the State of São Paulo, southeastern Brazil, (MENEZES \& FigueIREDO 1985; SAZIMA et al. 1999). Halichoeres irideus Starks, 1900 is a junior synonym.

\section{Halichoeres bivittatus (Bloch, 1791)}

Specimens examined. BRAZIL, Bahia: Ilha de Itaparica (12053'S), MZUSP 46355 (1), 79.5 mm, VII-1992, A. Carvalho Filho leg.; Rio de Janeiro: Angra dos Reis (2302'S), MZUSP 46190 (1), 132.0 mm, II-1992, A. Carvalho Filho leg.. 
Remarks. First substantiated record for the slippery dick in the western South Atlantic (RocHA et al. 1998). RANDALL \& BöHLKE (1965) mentioned the slippery dick from Brazil without any precise locality.

\section{Halichoeres maculipinna (Müller \& Troschel, 1848)}

Specimens examined. BRAZIL, Espírito Santo: Vitória (Ilha da Trindade, tidepool), ZUEC 3135 (2), 38.5-46.1 mm, 25-VIII-1995, J.L. Gasparini \& R.S. Floeter leg. .

Remarks. Previous southernmost known locality in northeastern Brazil, according to RANDALL \& BÖHLKE (1965) and MENEZES \& FIGUEIREDO (1985) who also comment on a small juvenile from Rio de Janeiro, southeastern Brazil, as possibly belonging to this species. We recorded this wrasse at several localities along the coast of the State of Espírito Santo.

\section{Thalassoma noronhanum (Boulenger, 1890)}

Specimens examined. BRAZIL, Bahia: Salvador, MZUSP 46823 (1), 61.0 mm, 9-VI-1993, C.L. Sampaio leg.; Espírito Santo: Vitória (Ilha da Trindade, 4 m), ZUEC 2684, 100.8 mm, 15-VIII-1995, J.L. Gasparini leg.; Guarapari (Ilha Escalvada, 2-3m), MZUSP 44666 (2), 104.0 and $113.0 \mathrm{~mm}$, 26-VI-1987, J.L. Gasparini leg.; São Paulo: Santos (Laje de Santos, 5 m), ZUEC 3146 (2), 59.2 and 80.4 mm, 17-XI-1996, R.L. Moura \& J.L. Gasparini leg..

Remarks. Previously recorded from St Paul's Rocks ( $\left.00^{\circ} 55^{\prime} \mathrm{N}, 29^{\circ} 20^{\prime} \mathrm{W}\right)$, the Fernando de Noronha Archipelago, Atol das Rocas and northeastern coast of Brazil (BOULENGER 1890; LUBBOCK \& EDWARDS 1981; RAMOS 1994; ROCHA et al. 1998). Specimens identified as T. bifasciatum (Bloch, 1791) from northeastern Brazil (RAMOS \& VASCONCELOS-FILHO 1989) were examined by us and actually belong to T. noronhanum. Records of T. bifasciatum along the Brazilian coast are based on misidentifications (RAMOS \& VASCONCELOS-FILHO 1989; RAMOS 1994) or even guesses (CARVALHO-FILHO 1992).

\section{Scaridae}

\section{Cryptotomus roseus Cope, 1871}

Specimens examined. BRAZIL, São Paulo: São Sebastião (Arquipélago dos Alcatrazes, 10 m), MZUSP 45646 (1), 79.0 mm, 28-VI-1993, R.L. Moura leg. .

Remarks. Previously recorded south to the State of Bahia, the type locality (COPE 1871). Additional records for Brazilian scarids will be dealt with in another paper, since several taxonomic problems were detected regarding the parrotfishes from the western South Atlantic.

\section{Tripterygiidae}

\section{Enneanectes altivelis Rosenblatt, 1960}

Specimens examined. Brazil, Rio Grande do Norte: Atol das Rocas, MZUSP 48897 (12), 10.8-27.1 mm, XII-1994, R.S. Rosa \& R.L. Moura leg.; Bahia:

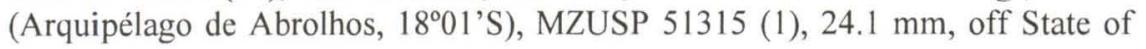


Bahia, 10-15-I-1997, I. Sazima, C. Sazima, J.L. Gasparini \& R.L. Moura leg.; Espírito Santo: Guarapari (Ilha Escalvada), MZUSP 51320 (4), 20.2-24.0 mm, 26-I-1977, I. Sazima, C. Sazima, J.L. Gasparini \& R.L. Moura leg.; Rio de Janeiro: (Baía da Ilha Grande, 2308' S), UFRJ 3493 (1), R.Z.P. Guimarães leg..

Remarks. Represents a south range extension of the lofty triplefin in the western South Atlantic, and the first record in a Brazilian oceanic island; previously recorded at Paraíba, northeastern Brazil (RochA et al. 1998).

\section{Dactyloscopidae}

\section{Storrsia olsoni Dawson, 1982}

Specimens examined. BRAZIL, Rio Grande do Norte: Atol das Rocas, MZUSP 48265 (3), 20.8-29.7 mm, 16-XII-1994-10-I-1995, R.L. Moura \& C.L.B. Francini leg. .

Remarks. Represents a range extension, since this stargazer was known only from the holotype from the Fernando de Noronha Archipelago (DAwSON 1982).

\section{Labrisomidae}

\section{Paraclinus nigripinnis (Steindachner, 1867)}

Specimens examined. BRAZIL, Santa Catarina: Porto Belo, MZUSP 46638 (3), 23.6-42.0 mm, Porto Belo, I-1988, A. Carvalho Filho leg. .

Remarks. Previously recorded south to the State of São Paulo, southeastern Brazil (MENEZES \& FIGUEIREDO 1985).

\section{Chaenopsidae}

\section{Emblemariopsis signifera (Ginsburg, 1942)}

Specimens examined. BraZIL, São Paulo: Ubatuba (Ilha da Vitória, 234ㄴ'S), MZUSP 46414 (4), 16.2-19.0 mm, 10-I-1993, J.M. Nogueira leg.; Santos (Laje de Santos, 8 m), MZUSP 44608 (2), 20.7 and 25.2 mm, 6-I-1991, R.L. Moura leg.; Itanhaém (Ilha da Queimada Grande), MZUSP 44610 (1), 19.5 mm, 15-VI1991, R.L. Moura leg..

Remarks. Previously recorded south to Angra dos Reis, State of Rio de Janeiro (MENEZES \& FigUEIREDO 1985). This species is expected to occur further south, at least to the State of Santa Catarina, since it is still abundant on the São Paulo State coast, from where our specimens were obtained.

\section{Blenniidae}

\section{Ophioblennius atlanticus (Cuvier \& Valenciennes, 1836)}

Specimens examined. BRAZIL, Espirito Santo: Guarapari (Três Ilhas), ZUEC 1952 (1), 100.7 mm, 7-II-1987, J.L. Gasparini leg.; São Paulo: Santos (Laje de Santos, 8 m), MZUSP 44607 (1), 60.0 mm, 6-I-1991, R.L. Moura leg..

Remarks. Previously recorded south to the State of Bahia, northeastern Brazil and the Ilha da Trindade, off State of Espírito Santo (SPRINGER 1962; MENEZES \& FigueIREDO 1985). 


\section{Eleotridae}

\section{Erotelis smaragdus (Valenciennes, 1837)}

Specimens examined. BRAZIL, Espírito Santo: Serra (Nova Almeida, 2004’S), MZUSP 51314 (1), 78.9 mm, 14-IX-1980, J.L. Gasparini leg. .

Remarks. Previously recorded south to the State of Bahia, northeastern Brazil (MENEZES \& FiguEIREDO 1985).

\section{Gobiidae}

\section{Bathygobius mystacium Ginsburg 1947}

Specimens examined. BRAzIL, Espirito Santo: Serra (Praia de Manguinhos, $20^{\circ} 11^{\prime}$ S, tidepool), ZUEC 2661-2674 (14), 20.3-40.4 mm, 18-III-1985, C. Zamprogno leg..

Remarks. First substantiated record for the island frillfin in the western South Atlantic (CARVALHO-FILHO 1992); previous southernmost record in the Caribbean (GINSBURG 1947; BÖHLKE \& CHAPLIN 1968).

\section{Coryphopterus glaucofrenum Gill, 1836}

Specimens examined. BRAZIL, Rio de Janeiro: Parati (Ilha Comprida), MZUSP 46200 (1), 36.4 mm, VII-1992, A. Carvalho Filho leg.; São Paulo: São Sebastião (Arquipélago dos Alcatrazes, $15 \mathrm{~m}$ ), MZUSP 44606 (1), $49.4 \mathrm{~mm}$, 26-IV-1991, R.L. Moura leg.; Itanhaém (Ilha da Queimada Grande, 18 m), MZUSP 44605 (1), 45.5 mm, 15-VI-1991, R.L. Moura leg..

Remarks. Previously recorded south to Angra dos Reis, State of Rio de Janeiro (MENEZES \& FIGUEIREDO 1985). This fish is expected to occur further south, at least to the State of Santa Catarina, since it is one of the commonest gobies on the sand of reef habitats on islands along the coast of the São Paulo State.

\section{Gnatholepis thompsoni Jordan, 1902}

Specimens examined. BraZIL, São Paulo: São Sebastião (Arquipélago dos Alcatrazes), MZUSP 46728 (1), 62.5 mm, 15-IV-1994, R.L. Moura leg. .

Remarks. Previously recorded from the Atol das Rocas and continental northeastern Brazil south to the State of Pernambuco (MENEZES \& FIGUEIREDO 1985; RAMOS 1994).

\section{Gobionellus saepepallens Gilbert \& Randall, 1968}

Specimens examined. BrazIL, São Paulo: São Sebastião (Praia de Baraqueçaba), MZUSP 46215 (3), 26.7-29.3 mm SL, I-1993, A. Carvalho Filho leg..

Remarks. Previously recorded in the western South Atlantic from the State of Rio de Janeiro (GUIMARÃES 1996b). Specimens from the State of Bahia were previously identified as Gobionellus comma Gilbert \& Randall, 1979 (MENEZES \& FIGUEIREDO 1985).

\section{Parrella macropteryx Ginsburg, 1939}

Specimens examined. BRAZIL, Santa Catarina: Porto Belo, MZUSP 46663 (30), 24.1-41.9 mm, I-1988, A. Carvalho Filho leg. .

Remarks. This goby is recorded from the Caribbean (Cuba), and São Sebastião, southeastern Brazil (MENEZES \& FIGUEIREDO 1985). 


\section{Microdesmidae}

\section{Microdesmus bahianus Dawson, 1973}

Specimens examined. Brazil, Alagoas: Maceió (Ponta Verde, 09³9'S, tidepool), MZUSP 49210 (1), 51.2 mm, 14-XII-1973, N.A. Menezes leg. .

Remarks. Represents a north range extension. This wormfish was described from Arembepe, State of Bahia, northeastern Brazil by DAwSON (1973), who also commented upon a Martinique specimen (ANSP 103427) as possibly belonging to this species.

\section{Ptereleotris helenae (Randall, 1968)}

Specimens examined. BRAZIL, São Paulo: São Sebastião (Arquipélago dos Alcatrazes, 8 m), MZUSP 45743 (1), 71.5 mm, 27-IV-1993, R.L. Moura leg..

Remarks. First substantiated record in the western South Atlantic (CARVALHO-FILHO 1992), since the southernmost record for the hovering goby was in the Caribbean (RANDALL 1968; HuMANN 1994).

\section{Acanthuridae}

\section{Acanthurus coeruleus Bloch \& Schneider, 1801}

Specimens examined. BRAZIL, São Paulo: Ubatuba (Ilha Anchieta), MZUSP 50569 (1), 225.0 mm, II-1996, H. Gallo leg. .

Remarks. Previously recorded south to the State of Rio de Janeiro, southeastern Brazil (RANDALL 1983).

\section{Reef fish distribution in the eastern coast of South America}

Along the Brazilian coast, reef habitats range from offshore reefs in the State of Maranhão to rocky reefs on the coast of the State of Santa Catarina, the southernmost limit of rocky reef bottoms under permanent influence of the warm Brazil Current (EvANS et al. 1985; STRAMMA 1989). Reef fish assemblages on the eastern coast of South America are composed by: 1) circuntropical and Pan-Atlantic species (BRIGGS 1960); 2) species widely distributed in the Western tropical Atlantic; 3) species occuring on the eastern and northern coast of South America (Blasiola 1976), and 4) Brazilian Province endemics (GrEENFIELD 1988, 1989; MoURA 1995; SAZIMA et al. 1997, 1998).

There is a steadily growing evidence that a sizable portion of the Brazilian reef ichthyofauna is endemic to the western South Atlantic (GREENFIELD 1988, 1989; Moura 1995; SAZIMA et al. 1997, 1998). Of special interest is the fact that some supposedly Caribbean reef fish species recorded for the Brazilian coast proved later to be undescribed species endemic to the Brazilian Province (SAZIMA et al. 1997,1998 ). Additional revisionary studies will probably show that the same is true for some species dealt with in the present paper.

Oceanic islands off Brazil harbor a considerable number of endemic species, which are very abundant locally (EDWARDS \& LUBBOCK 1983a; ROSA \& MOURA 1997). The Saint Paul's Rocks harbor 12 endemic shore fish species and share 6 
species only with islands of the Mid Atlantic Ridge (LUBBOCK \& EDWARDS 1981; EDWARDS \& LUBBOCK 1983b). The two insular groups within the Fernando de Noronha Ridge, Atol das Rocas and the Fernando de Noronha Archipelago, present a very similar shore fish fauna, with about four endemic shore fish species (MOURA \& ROSA 1997). The ichthyofauna of the Trindade and Martin-Vaz islands is very poorly known (MIRANDA-RIBEIRO 1919; ANDREATA \& SÉRET 1995), but at least one endemic locally abundant shore fish species is present.

Although there is a considerable homogeneity in the composition of reef fish faunas within the Brazilian Province, there are some latitudinal trends possibly related to salinity, bottom type, and temperature. The northern limit of reef fish distribution within the Province is poorly known, due to an almost complete lack of collections along the coast of northern Brazil. Offshore reefs of the State of Maranhão, such as the Parcel Manoel Luís, represent the northern outposts of this fauna, separated from the Southern Caribbean by hypossaline waters (ALLERSMA 1971) and mud bottoms (ARAGNO 1971) off the mouths of the Mearim, Amazon and Orinoco rivers. Only a small number of reef fish species occur on the "stepping stones" (offshore sponge bottoms) between these two areas (COLLETTE \& RUTZLER 1977).

The largest coral reef assemblage along the Brazilian coast is located in the Archipelago of Abrolhos, off the southern State of Bahia (HETZEL \& CASTRO 1994; LEÃO et al. 1988) and, as a consequence, the greatest reef fish species richness is expected to occur in this area, in spite of the very few fish collections from there. A preliminary study carried out by the authors in the Abrolhos area yielded about 150 reef fish species (unpubl. data).

From the coast of Bahia through Santa Catarina there is a latitudinal decrease in the number of coral (LEÃO et al. 1988) and reef fish species, probably related to water temperature and bottom configuration, the reef habitats gradually changing from coral reefs to rocky bottom with sparse coral heads. Very few reef fish species (e.g. Chromis jubauna, Ribeiroclinus eigenmanni) occur exclusively in the cooler waters south to the rich coral reef growth limits with increasing seasonal influence of the Falklands Current (STRAMMA 1989; Moura 1995).

At its southernmost limit, the reef fish fauna is very impoverished and most species remain restricted to the continental islands off Santa Catarina (unpubl. data). Within this transition area, only juveniles of some reef fish species are found and occasional occurrences south to Argentina and Uruguay (ASTARLOA \& FIGUEIROA 1995; LUENGO 1968) are based on stray individuals, probably recruited south of their habitual distribution range (ZAVALA-CAMIN 1986). From Santa Catarina south, hard bottom occurs only in occasional and sparse patches, and the cool and turbid waters of the Falklands Current (LEMA et al. 1980) represent a serious obstacle for the establishment of permanent reef fish communities.

ACKNOWLEDGEMENTS. We thank A. Carvalho Filho for collecting many specimens, and for his field notes and photographs; J.L. Figueiredo and N.A. Menezes for review of the text, and permission to examine material under their care; R.S. Rosa for loan of specimens under his 
care, help with the fieldwork and suggestions; A.P. Almeida, B. P. Ferreira, C.E.L. Ferreira, R.Z.P. Guimarães, D.A. Jório, C.L. Sampaio, and J. Scalfone for collecting specimens; S.R. Floeter, C.L.B. Francini, S.S. Mendes, M.C.M. Rodrigues, R.B. Francini, G.L. Moura, J.C.G. Pereira, C. Sazima, D.V. Vervloet, and V.C. Vidal for help with the fieldwork; A. Maluf for help with the ZUEC collection; O.B.F. Gadig for identification of $C$. perezi; the Ibama (through H.M. Bulhões, G. Sales and M.B. Silva) for the opportunity to work at the Arquipélago dos Abrolhos and Atol das Rocas; the Brazilian Navy (through the $1^{\text {st }}$ and $2^{\text {nd }}$ Distrito Naval da Marinha do Brasil) and the Tamar/Ibama (through L. Magnabosco) for the opportunity to work on the Arquipélago dos Abrolhos and the Ilha da Trindade; the Instituto Florestal (through F.P. Campos and M.A. Fontes) for the opportunity to work on the P.E. Ilha Anchieta and on the islands along the coast of the State of São Paulo; the Aquário de Ubatuba (through $\mathrm{H}$. Gallo) for donation of the specimen of A. coeruleus; the CNPq (grant 300992/79 to IS), the FAPESP (grants $96 / 0927-0$ and $98 / 03491-3$ to RLM and 96/5328-8 to IS) and the Finep/Pronex (grant 058-97 to Naércio A. Menezes) for essential financial support.

\section{REFERENCES}

ACERo, A. \& J. GARzón. 1982. Rediscovery of Anisotremus moricandi (Perciformes: Haemulidae), including a rediscription of the species and comments on its ecology and distribution. Copeia 1982 (3): 613-618.

Allersma, E. 1971. Mud on the oceanic shelf off Guiana. Symposium on investigations and resources of the Caribbean Sea and adjacent regions, Unesco, p.193-203.

AlmeidA, V.G. 1973. New records of tidepool fishes from Brazil. Pap. Avulsos Zool., São Paulo, 26 (14): 187-191.

ANDREATA, J.V. \& B. SÉRET. 1995. Relação dos peixes coletados nos limites da plataforma continental e nas montanhas submarinas Vitória, Trindade e Martin Vaz, durante a Campanha Oceanográfica MD-55 Brasil. Revta bras. Zool. 12 (3): 579-594.

ARAGNO, F.J. 1971. Derrame de las aguas del Rio Orinoco en el Mar Caribe sudoriental. Symposium on investigations and resources of the Caribbean Sea and adjacent regions, Unesco, p.27-30.

AstarloA, J.M.D. \& D.E. FigueIROA. 1995. Scrawled cowfish, Acanthostracion quadricornis (Tetraodontiformes: Ostraciidae), collected from Argentine waters. Japan Jour. Ichthyol. 41 (4): 466-468.

Blasiola JR., G.C. 1976. Centropyge aurantonotus Burgess, 1974: range extension and redescription. Bull. Mar. Sci. 26 (4): 564-568.

BLUMER, L.S. 1982. A bibliography and categorization of bony fishes exhibiting parental care. Zool. Jour. Linn. Soc., London, 76: 1-22.

BÖHLKE, J.E. \& C.C.G. CHAPLIN. 1968. Fishes of the Bahamas and adjacent tropical waters. Wynnewood, Livingston Publ. Co., 771p.

BÖHLKE, J.E. \& J.E. RANDALl. 1968. A key to the shallow-water West Atlantic cardinalfishes (Apogonidae), with description of five new species. Proc. Acad. nat. Sci. Philad. 120 (4): 175-206.

BOULENGER 1890. Pisces, p.483. In: H.N. RIDLEY (Ed.). Notes on the Zoology of Fenando Noronha. Jour. Linn. Soc. 20: 473-487. 
BRADBURY, M.G. 1967. The genera of batfishes (family Ogcocephalidae). Copeia 1967 (2): 399-422.

BRIGGS, J.C. 1960. Fishes of worldwide (circuntropical) distribution. Copeia 1960 (3): $171-180$.

Carvalho-Filho, A. 1992. Peixes: costa brasileira. São Paulo, Ed. Marca D’Água, $2^{\mathrm{a}}$ ed., 304p.

Cervigón, F. 1966. Los peces marinos de Venezuela. Caracas Fund. La Salle Cienc. nat., Estac. mar. Margarita, Vol. 2, p.449-961.

CHAO, L.N. 1978. Sciaenidae. In: W. FISCHER (Ed.). FAO species identification sheets for fishery purposes. Western Central Atlantic (fishing area 31). Roma, FAO, Vol. 1-7.

CHARNEY, P. 1976. Oral brooding in the cardinal-fishes Phaeoptyx conklini and Apogon maculatus from the Bahamas. Copeia 1976 (1): 198-200.

Collette, B.B. \& K. RUtZleR. 1977. Reef fishes over sponge bottoms off the mouth of the Amazon River. Proc. $3^{\text {rd }}$ Int. Coral Reef Symp.: 305-310.

COPE, E.D. 1871. Contribution to the ichthyology of the Lesser Antilles. Trans. American Philos. Soc., new. ser., 14 (3): 445-483.

Courtenay, 1967. Atlantic fishes of the genus Rypticus (Grammistidae). Proc. Acad. nat. Sci. Philad. 119 (6): 241-293.

DAwson, C.E. 1973. Microdesmus bahianus, a new western Atlantic wormfish (Pisces: Microdesmidae). Proc. Biol. Soc. Wash. 86: 203-210.

1982. Atlantic sand stargazers (Pisces: Dactyloscopidae), with description of one new genus and seven new species. Bull. mar. Sci. 32 (1): 14-85.

EDWARDS, A.J. \& R. LUBBOCK. 1983a. Marine zoogeography of St. Paul's Rocks. Jour. Biogeogr. 1983 (10): 65-72.

1983b. The ecology of Saint Paul's Rocks (Equatorial Atlantic). Jour. Zool., London, 200: 51-69.

Evans, D.L.; S.L. Signorini \& L.B. MiRANDA. 1985. A note on the transport off the Brazil Current. Jour. Phys. Oceanogr. 13: 1732-1738.

FERREIRA, B.P.; M. MAIDA \& A.E.T. SoUZA. 1995. Levantamento inicial das comunidades de peixes recifais da região de Tamandaré - PE. Bol. Técn. Cient. Cepene, Tamandaré, 3 (1): 211-230.

FigueIREDO, J.L. 1978. Manual de peixes marinhos do sudeste do Brasil. I. Introdução. Cações, raias e quimeras. São Paulo, Museu de Zoologia, Univ. São Paulo, 104p.

FigUEIREDO, J.L. \& N.A. MENEZES. 1978. Manual de peixes marinhos do sudeste do Brasil. II. Teleostei (1). São Paulo, Museu de Zoologia, Univ. São Paulo, $110 \mathrm{p}$.

1980. Manual de peixes marinhos do sudeste do Brasil. III. Teleostei (2). São Paulo, Museu de Zoologia, Univ. São Paulo, 90p.

GiLBERT, C. 1977. Status of the western South Atlantic apogonid fish Apogon americanus, with remarks on other Brazilian Apogonidae. Copeia (1): 25-32.

GINSBURG, I. 1947. American species and subspecies of Bathygobius, with a demonstration of a suggested modified system of nomenclature. Jour. Wash. Acad. Sci. 37 (8): 275-284.

GonZÁlez-Lorenzo, G.; A. Brito; J.M. Falcón \& P. PAscual-Alayón. 1995. 
About the taxonomic status of the garden-eels Heteroconger longissimus Günther 1870 and Heteroconger halis (Böhlke 1957) (Pisces, Congridae, Heterocongrinae). Bull. Mar. Sci. 57 (2): 550-555.

GREENFIELD, D.W. 1988. A review of the Lythrypnus mowbrayi complex (Pisces: Gobiidae), with a description of a new species. Copeia (2): 460-470.

- 1989. Priolepis dawsoni n.sp. (Pisces: Gobiidae), a third Atlantic species of Priolepis. Copeia 1989 (2): 397-401.

GuIMARÃES, R.Z.P. 1996a. First record of Apogon planifrons Longley et Hildebrand (Teleostei: Apogonidae) from southeastern Brazil. Rev. fr. Aquariol. 23 (1-2): 61-63.

1996b. Three new records of marine gobiid fishes (Teleostei: Gobiidae) from southeastern Brazil. Rev. fr. Aquariol. 23 (1-2): 64-68.

Hetzel, B. \& C.B. Castro. 1994. Corais do sul da Bahia. Rio de Janeiro, Ed. Nova Fronteira, 189p.

HumanN, P. 1994. Reef fish identification: Florida, Caribbean, Bahamas. Orlando, Vaughan Press, $2^{\text {nd }}$ ed., $396 \mathrm{p}$.

KoIKE, J. \& D.S. Guedes. 1981. Peixes dos arrecifes de Pernambuco e estados vizinhos, p.35-83. In: N. BANKS (Ed.). Anais do III Encontro de Zoologia do Nordeste. Recife, Univ. Fed. Rural Pernambuco, 115p.

LEÃO, Z.M.A.; T.M.F. ARAUJO \& M.C. NolasCO. 1988. The coral reefs off the coast of eastern Brazil. Proc. $6^{\text {th }}$ Int. Coral Reef Symp: 339-347.

LEMA, T. 1979. Presença de Equetes lanceolatus (L. 1758) na costa marinha do Rio Grande do Sul (Teleostei - Perciformes -Sciaenidae). Iheringia, Ser. Zool., Porto Alegre, 54: 17-19.

LEMA, T.; C.A.S. LUCENA \& Z.M.S. LUCENA. 1980. Novas adendas à ictiofauna marinha do extremo sul do Brasil (Actinopterygii: Teleostei). Iheringia, Ser. Zool., Porto Alegre, 56: 103-120.

LUBBOCK, R. \& A.J. EDWARDS. 1981. The fishes of Saint Paul's Rocks. Jour. Fish Biol. 18: 135-157.

LuENGO, J.A. 1968. Una nueva familia para el Uruguay (Pisces, Ostraciontidae). Neotropica 28: 9-10.

Mago-LecCiA, F. 1965. Nuevas adiciones a la ictiofauna de Venezuela. I. Acta Biol. Ven. 4 (13): 365-420.

McCosker, J.E.; E.B. BöHLKE \& J.E. BöHLKE. 1989. Family Ophichthidae, p.254-412. In: E.B. BöHLKE (Ed.). Fishes of the Western Atlantic. New Haven, Mem. Sears. Found. Mar. Res., Part 9, Vol. 1., 655p.

MENEZES, N.A. \& J.L. FigUEIREDO. 1980. Manual de peixes marinhos do sudeste do Brasil. IV. Teleostei (3). São Paulo, Museu de Zoologia, Univ. São Paulo, 96p.

(4). São Paulo, Museu de Zoologia, Univ. São Paulo, 105p.

Miranda-Ribeiro, P.A. 1919. A fauna vertebrada da Ilha de Trindade. Arch. Mus. Nac. Rio Janeiro 22: 171-194.

MourA, R.L. 1995. A new species of Chromis (Perciformes: Pomacentridae) from the southeastern coast of Brazil, with comments on other species of the genus. Rev. fr. Aquariol. 21 (3-4): 91-96. 
MouRA, R.L. \& R.S. RosA. 1997. Visual assessment of reef fish community structure in the Atol das Rocas Biological reserve, off Northeastern Brazil. Proc. Int. Coral Reef Symp. 8 (1): 983-986.

NELSON, J.S. 1994. Fishes of the world. New York, John Wiley \& Sons, $3^{\text {rd }}$ ed., $600 \mathrm{p}$.

Pietsch, T.W. \& D.B. Grobecker. 1987. Frogfishes of the world. Stanford, Stanford Univ. Press., 420p.

RAMOS, R.T.C. 1994. Análise da composição e distribuição da fauna de peixes demersais da plataforma continental da Paraíba e estados vizinhos. Rev. Nordestina Biol. 9 (1): 1-30.

RAMOS, R.T.C. \& A.L. VASCONCELOS-FiLHo. 1989. Novas ocorrências de peixes marinhos demersais para a costa Nordeste do Brasil. Trab. Ocanogr. Univ. Fed. Pernambuco 20: 197-202.

Randall, J.E. 1968. Caribbean reef fishes. Neptune City, TFH Publications, $318 \mathrm{p}$. ed., 350p.

RANDALL, J.E. \& J.E. BöHLKE. 1965. A review of the Atlantic labrid fishes of the genus Halichoeres. Proc. Acad. nat. Sci. Philad. 117 (7): 235-259.

Rocha, L.A.; I.L. Rosa \& R.S. RosA. 1998. Peixes recifais da costa da Paraíba, Brasil. Revta bras. Zool. 15 (2): 553-566.

RosA, R.S. 1980. Lista sistemática de peixes marinhos da Paraíba (Brasil). Rev. Nordestina Biol. 3 (2): 205-226.

RouX, C. 1973. Résultats scientifiques des campagnes de la "Calypso". Fasc. $X$. Campagne de la Calypso au large de côtes atlantiques de l'Amerique du Sud (1961-1962). Premiére partie (suite). 26. Poissons téléostéens du plateau continental Brésilien. Paris, Masson et Cie., 207p.

1979. Résultats scientifiques des campagnes de la "Calypso". Fasc. XI. Campagne de la Calypso au large de côtes atlantiques de l'Amerique du Sud (1961-1962). Premiére partie (suite). 30. Poissons chondrichthyens du plateau continental Brésilien et du Rio de La Plata. Paris, Masson et Cie., $130 \mathrm{p}$.

SaldanHa, L.; G. Maul; M. Biscoito \& F. ANDRAde. 1986. On the identity of Heteroconger longissimus Günther, 1870 and Heteroconger halis (Böhlke, 1957) (Pisces, Congridae). Bocagiana 104: 1-17.

SAZIMA, I.; J.L. GASPARINI \& R.L. MouRA. 1998. Gramma brasiliensis, a new basslet from the western South Atlantic (Perciformes: Grammatidae). Aqua Jour. Ichthyol. Aq. Biol. 3 (1): 39-43.

SAZIMA, I.; R.L. MouRA \& J.L. GASPARINI. 1999. The wrasse Halichoeres cyanocephalus (Labridae) as a specialized cleaner fish. Bull. Mar. Sci. 63: 605-610. SAZIMA, I.; R.L. MouRA \& R.S. RosA. 1997. Elacatinus figaro sp.n. (Perciformes: Gobiidae), a new cleaning goby from the western South Atlantic. Aqua Jour. Ichthyol. Aq. Biol. 2 (3): 33-38.

SMith, D.G. 1989. Family Congridae, p.406-567. In: E.B. BöHLKE (Ed.). Fishes of the Western Atlantic. New Haven, Mem. Sears. Found. Mar. Res., Part 9, Vol. 1, 655p. 
SPRINGER, V.G. 1962. A review of the blenniid fishes of the genus Ophioblennius Gill. Copeia 1962 (2): 426-433.

STARNES, W.C. 1988. Revision, phylogeny and biogeographic comments on the circumtropical marine percoid fish family Priacanthidae. Bull. Mar. Sci. 43 (2): 117-203.

Stramma, I. 1989. The Brazil Current transport south of $23^{\circ}$ S. Deep Sea Res. 36 (4): 639-646.

ZAVALA-CAMIN, L.A. 1986. Possíveis estratégias de distribuição e retorno de peixes brefoepipelágicos do Brasil $\left(20^{\circ} \mathrm{S}-32^{\circ} \mathrm{S}\right)$. Bol. Inst. Pesca, São Paulo, 13 (2): 103-113.

Recebido em 20.VI.1997; aceito em 26.IV.1999. 